\title{
[Regular Paper] \\ Roles of Promoter and Support of Sulfided Mo-based Catalyst in Selective Hydrotreating of Palm Fatty Acid Distillate
}

\author{
Kihoon Kim, Yusei Kawano, Daisuke Higai, Xiaofan Hou, Mingming Peng, and Eika W. QIAN* \\ Graduate School of Bio-Applications and Systems Engineering, Tokyo University of Agriculture and Technology, \\ Nakacho 2-24-16, Koganei, Tokyo 184-8588, JAPAN
}

(Received July 29, 2021)

\begin{abstract}
A series of $\mathrm{CoMo} / \mathrm{Al}_{2} \mathrm{O}_{3}$ catalysts with various $\mathrm{Co} / \mathrm{Mo}$ mole ratios and a series of $\mathrm{CoMo} / \mathrm{TiO}_{2}-\mathrm{Al}_{2} \mathrm{O}_{3}$ catalysts supported on $\mathrm{TiO}_{2}$ coating $\mathrm{Al}_{2} \mathrm{O}_{3}$ were prepared. The effects of $\mathrm{Co} / \mathrm{Mo}$ mole ratio and $\mathrm{TiO}_{2}$ loadings on $\mathrm{Al}_{2} \mathrm{O}_{3}$ on hydrodeoxygenation (HDO) and decarboxylation/decarbonylation (DCO) in the hydrotreating of palm fatty acid distillate (PFAD) were investigated. The catalysts were characterized by BET, XRF, pulse NO chemisorption, and $\mathrm{H}_{2}$-TPR. The maximum yields of $n-\mathrm{C}_{16}$ and $n$ - $\mathrm{C}_{18}$ was observed at $\mathrm{Co} / \mathrm{Mo}=0.05$ for the $\mathrm{CoMo} / \mathrm{Al}_{2} \mathrm{O}_{3}$ series, and the yield of $n-\mathrm{C}_{15}$ and $n-\mathrm{C}_{17}$ was increased at $\mathrm{Co} / \mathrm{Mo}>0.05$. CoMoS phase apparently has both HDO and DCO activities. CoMo(0.05)/Ti(20)-Al showed the maximum yields of $n$ - $\mathrm{C}_{16}$ and $n-\mathrm{C}_{18}$ due to the formation of TiMoS in all catalysts. TiMoS phase may be formed by adding $\mathrm{TiO}_{2}$ on $\mathrm{Al}_{2} \mathrm{O}_{3}$ and promotes the $\mathrm{HDO}$ reaction, but not isomerization or cracking.
\end{abstract}

\section{Keywords}

Hydrodeoxygenation, Titania alumina support, Cobalt molybdenum catalyst, Palm fatty acid distillate, Metal support interaction, Phase change material

\section{Introduction}

Latent heat storage systems using Phase Change Material (PCM) are an effective method for storing thermal energy, such as solar energy which practically inexhaustible so will be significant in building a sustainable society ${ }^{1), 2)}$. Paraffins $\left(n-\mathrm{C}_{16}\right.$ and $\left.n-\mathrm{C}_{18}\right)$ are considered one of the best primary raw materials for PCMs because of the non-hazardous, easy to handle, and stable characteristics ${ }^{3)}$. In addition, $n-\mathrm{C}_{16}$ and $n-\mathrm{C}_{18}$ have higher latent heat than $n-\mathrm{C}_{15}$ and $n-\mathrm{C}_{17}$ in the optimum temperature range for humans ${ }^{4)}$. However, sustainable energy generation requires that paraffin should be made from vegetable oils, not petroleum. The desirable PCM components can be produced through hydrodeoxygenation (HDO) of vegetable oil ${ }^{4) ~ 9)}$. A previous study produced $66.4 \%$ of $n-\mathrm{C}_{16}$ and $n-\mathrm{C}_{18}$ from palm fatty acid distillate (PFAD) using PtSn/ALPO-11. However, the HDO selectivity was still insufficient for industrialization.

Transition metal sulfide (TMS) catalysts are the most critical industrial catalysts used in hydrotreating processes such as hydrodesulfurization and hydrodenitro-

DOI: doi.org/10.1627/jpi.65.18

* To whom correspondence should be addressed.

* E-mail: whqian@cc.tuat.ac.jp genation. NiMo and CoMo are well known to exhibit higher activity than single metal catalysts due to their "synergy effect"11); the "ensemble effect" caused by specific geometry, and the "ligand effect" due to the electronic interaction. Modifications of the mole ratio of $\mathrm{Co} /(\mathrm{Co}+\mathrm{Mo})$ by changing the loading amount of Mo for HDO of 4-methylphenol showed the conversion of 4-methyl phenol over all catalysts was close to $100 \%$, and the selectivity for toluene was $87.9 \%$ over $\mathrm{CoMo} / \mathrm{ZrO}_{2}(0.30)^{12)}$. However, the effect of the mole ratio on selective hydrotreating of vegetable oil has not been fully investigated using $\mathrm{Co} / \mathrm{Mo}$ ratios lower than 0.35. In addition, the effect of the loading amount of Co is still unclear.

The deoxygenation mechanisms occurring on TMS catalysts are mainly HDO and decarboxylation/decarbonylation (DCO). Therefore, the deoxygenation activity of the catalyst involves the support as well. For example, $\gamma-\mathrm{Al}_{2} \mathrm{O}_{3}$ has considerable activity in deoxygenation reactions due to its Lewis acid sites ${ }^{13)}$. However, $\mathrm{Al}_{2} \mathrm{O}_{3}$ only has considerable activity due to its strong metal-support interaction ${ }^{14)}$. Therefore, we previously applied $\mathrm{TiO}_{2}$ to overcome the disadvantages of $\mathrm{Al}_{2} \mathrm{O}_{3}$ and improve the common catalytic activity ${ }^{15}$. The carboxylic group of a fatty acid ester may adsorb on the surface of $\mathrm{TiO}_{2}{ }^{17), 18)}$. CoMo catalysts supported on $\mathrm{TiO}_{2}$ among the CoMo catalysts supported on $\mathrm{TiO}_{2}$, 
$\mathrm{ZrO}_{2}, \mathrm{Al}_{2} \mathrm{O}_{3}, \mathrm{MCM}-41$, and $\mathrm{MgO}$ exhibited the highest $\mathrm{C} n / \mathrm{C}(n-1)$ selectivity, i.e. inherent HDO selectivity ${ }^{18)}$. However, the problem with $\mathrm{TiO}_{2}$ is the lower activity than $\mathrm{Al}_{2} \mathrm{O}_{3}$ due to its low specific surface area (140 $\left.\mathrm{m}^{2} / \mathrm{g}\right)^{18)}$. To solve this problem, $\mathrm{TiO}_{2}$ coating supports have been applied such as $\mathrm{TiO}_{2}-\mathrm{Al}_{2} \mathrm{O}_{3}$. $\mathrm{TiO}_{2}$ enhanced the reduction, formation, and stacking of CoMoS active slabs ${ }^{15), 16)}$. $\quad \mathrm{TiO}_{2}$ coated Mo-based sulfided catalyst showed increased of CoMoS and TiMoS formation. However, the effect of TiMoS active slab is still unclear.

Therefore, CoMo catalysts are good candidates for producing the PCM components ( $n-\mathrm{C}_{16}$ and $n-\mathrm{C}_{18}$ ) through hydrodeoxygenation of vegetable oil. However, more active catalysts for reaction at low temperatures are necessary. The effects of metal promoters on the hydrotreating reaction selectivity have been well investigated, but the effect of the active metal species Co and Mo ratio on the active metal species is unclear. In addition, the effects of Co and Mo on desulfurization reactions are well studied, but the mechanisms and effects on the selectivity and reaction rates of HDO and DCO reactions in vegetable oils are still unknown. The effect of $\mathrm{TiO}_{2}$ coated supports on the hydrogenation pathway of vegetable oils is also unclear. Therefore, we prepared catalysts supported on $\mathrm{Al}_{2} \mathrm{O}_{3}$ support with several ratios of $\mathrm{Co}$ and Mo for optimizing the $\mathrm{Co} /$ Mo mole ratio. Then, catalysts supported on $\mathrm{TiO}_{2}$ coated $\mathrm{Al}_{2} \mathrm{O}_{3}$ support with specific amounts of $\mathrm{Co}$ and Mo were prepared. Palm fatty acid distillate (PFAD) was chosen as a feedstock, because PFAD is the byproduct of the crude palm oil refinery process and is inexpensive. Also, PFAD has high durability to oxidation because of the low content of linolenic acid $(18: 3)$ and a high level of vitamin E, which acts as an antioxidant ${ }^{2), 25)}$. The effect of $\mathrm{Co} / \mathrm{Mo}$ mole ratio and $\mathrm{TiO}_{2}$ coating on $\mathrm{Al}_{2} \mathrm{O}_{3}$ on the deoxygenation activity, HDO yield $\left(n-\mathrm{C}_{16}+n-\mathrm{C}_{18}\right)$, and DCO yield $\left(n-\mathrm{C}_{15}+n-\mathrm{C}_{17}\right)$ of the catalyst were investigated.

\section{Experimental}

\section{1. Materials}

PFAD, a byproduct of the palm oil refining process, was used as the feedstock to evaluate the catalytic activity. Physical properties (density, dynamic viscosity, acid value, and cloud point), fatty acid composition, and element analysis (C, H, O, S) were determined previously ${ }^{2)}$. The density, dynamic viscosity, acid value, and cloud point are $0.86 \mathrm{~g} / \mathrm{cm}^{3}, 14.1 \mathrm{mPa} \mathrm{s} / 50{ }^{\circ} \mathrm{C}$, $195 \mathrm{mg} \mathrm{KOH} / \mathrm{g}$ and $45^{\circ} \mathrm{C}$, respectively. PFAD consists of $88.9 \%$ fatty acids and $11.1 \%$ triglycerides. Palmitic acid (C16:0) and oleic acid (C18:1) are the major fatty acids in PFAD, at $45.5 \mathrm{wt} \%$ and $38.8 \mathrm{wt} \%$, respectively. In addition, PFAD contains $3.9 \%$ of stearic acid, $9 \%$ of oleic acid, and trace amounts of other fatty acids.

\section{2. Catalyst Preparation}

Co and Mo supported catalysts were prepared by the conventional incipient wetness impregnation method ${ }^{20)}$. Commercial $\gamma-\mathrm{Al}_{2} \mathrm{O}_{3}$ (NK31925, Nippon Ketjen Co., Ltd.) was used as the support for the following impregnation. The catalysts were prepared using successive addition of aqueous solutions of $\mathrm{Co}\left(\mathrm{NO}_{3}\right)_{2}$ and $\left(\mathrm{NH}_{4}\right)_{6} \mathrm{Mo}_{7} \mathrm{O}_{24}$. After impregnation, the samples were dried at $120{ }^{\circ} \mathrm{C}$ for $2 \mathrm{~h}$ in air and then calcined at $450{ }^{\circ} \mathrm{C}$ for $10 \mathrm{~h}$ in air. The loading amount of $\mathrm{MoO}_{3}$ was fixed at $20 \mathrm{wt} \%$ and catalysts with several $\mathrm{Co} / \mathrm{Mo}$ ratios $\mathrm{CoMo}(X) / \mathrm{Al}_{2} \mathrm{O}_{3}(X=0.02,0.05,0.1,0.35)$ were prepared.

$\mathrm{TiO}_{2}$ coated $\mathrm{Al}_{2} \mathrm{O}_{3}$ support was synthesized as previously reported ${ }^{15}$. Titanium ethoxide (Sigma-Aldrich Co.) was used as the titania source. First, $\mathrm{Al}_{2} \mathrm{O}_{3}$ support, titanium ethoxide, and anhydrous ethanol with various amounts of $\mathrm{TiO}_{2} 10,15,20 \mathrm{wt} \%$ were added into an eggplant flask so that the air inside was replaced by nitrogen. Next, the eggplant flask was connected with the evaporator and slowly stirred for about $5 \mathrm{~h}$ at $85^{\circ} \mathrm{C}$ in a water bath until the anhydrous ethanol was fully vaporized. Then, the flask was filled with distilled water and stirred at $40{ }^{\circ} \mathrm{C}$ overnight to hydrolyze the titanium ethoxide. Finally, the formed solid was separated by suction filtration and calcinated at $600{ }^{\circ} \mathrm{C}$ for $4 \mathrm{~h}$. The prepared support samples are denoted as $\mathrm{Ti}(X)-\mathrm{Al}$ (Ti: added $\mathrm{TiO}_{2}, X$ : weight percentage). The loading amounts of $\mathrm{CoO}$ and $\mathrm{MoO}_{3}$ are the same as those of the $\mathrm{CoMo} / \mathrm{Al}_{2} \mathrm{O}_{3}$ catalysts, which showed the highest yield of $n-\mathrm{C}_{16}+n-\mathrm{C}_{18}$.

\section{3. Characterization of Catalysts}

Physical properties were measured by established methods. Specific surface areas and pore sizes of catalysts were calculated by using nitrogen physisorption at $-196{ }^{\circ} \mathrm{C}$ with a Belsorp-mini II automated sorption system (MicrotracBEL Corp.). Specific surface area was calculated using the Brunauer-Emmett-Teller method $^{21)}$ at a relative partial pressure of 0.05-0.3. Prior to the measurement, the sample was degassed under a vacuum $\left(p<10^{-2} \mathrm{kPa}\right.$ ) at $400{ }^{\circ} \mathrm{C}$ for $1 \mathrm{~h}$. The total pore volume and pore size distribution were measured by a desorption curve using the Barret-Joyner-Halenda model $^{22)}$ at a relative partial pressure of 0.95 .

The loading amounts of $\mathrm{CoO}, \mathrm{MoO}_{3}$, and $\mathrm{TiO}_{2}$ were determined by X-ray fluorescence (XRF) measurement using a Rayny EDX13 700/800XRF analyzer (Shimadzu Corp.). Catalyst samples $200 \mathrm{mg}$ were crushed, then compression molded into a shape disk before analyzing ${ }^{23)}$.

The dispersion of active metals was measured by the pulse NO chemisorption method ${ }^{15)}$ using a ChemBET Pulsar temperature-programmed reduction/temperature-programmed desorption (TPR/TPD) (Quantachrome Instruments Co.). Prior to adsorption, the desired amount of the calcined catalyst $(200 \mathrm{mg}$ ) was sulfided 
with $5 \% \mathrm{H}_{2} \mathrm{~S}$ in $\mathrm{H}_{2}$ at $100{ }^{\circ} \mathrm{C}$ for $1 \mathrm{~h}, 200{ }^{\circ} \mathrm{C}$ for $1 \mathrm{~h}$, $300{ }^{\circ} \mathrm{C}$ for $1 \mathrm{~h}$, and $400{ }^{\circ} \mathrm{C}$ for $3 \mathrm{~h}$, and then pretreated in a highly pure helium flow at the same temperature for $2 \mathrm{~h}$ to remove impurities, followed by cooling to $40{ }^{\circ} \mathrm{C}$. $10 \% \mathrm{NO} / \mathrm{He}$ gas pulses were gradually introduced into the catalyst loop through a calibrated injection valve $\left(250 \mu \mathrm{L} \mathrm{NO}\right.$ pulse $\left.^{-1}\right)$ at intervals of $10 \mathrm{~min}$ until the signal of the introduced NO pulse became constant.

$\mathrm{H}_{2}$-TPR measurements were carried out using the same instrument for NO pulse chemisorption and conventional measurements ${ }^{2)}$. The samples were first pretreated in a highly pure helium flow at $500{ }^{\circ} \mathrm{C}$ for $3 \mathrm{~h}$ to remove the adsorbed impurities and then were cooled down to $30{ }^{\circ} \mathrm{C}$, followed by changing the gas to 5 vol\% $\mathrm{H}_{2}$ in an argon gas mixture $(15 \mathrm{~mL} / \mathrm{min}) . \quad \mathrm{H}_{2}$-TPR was performed by linearly increasing the temperature to $1000{ }^{\circ} \mathrm{C}$ with a heating rate of $5{ }^{\circ} \mathrm{C} / \mathrm{min}$. Thermal conductivity detectors (TCD) were used to monitor hydrogen consumption.

\section{4. Activity Test of Catalysts}

Details of our experimental reactor were reported earlier ${ }^{24)}$. PFAD was chosen for the feedstock. Bis-(1,1,3,3-tetramethylbutyl)-pentasulfide CS-40 (DIC Corp.), which decomposes during the reaction to generate hydrogen sulfide, was mixed in PFAD at $0.1 \mathrm{wt} \%$ to prevent deactivation of the catalyst. The molecular structure and physical properties of CS-40 are shown in the Appendix (Fig. A-1 and Table A-1). Catalysts $\left(9 \mathrm{~cm}^{3}\right)$ were mixed with quartz $\left(21 \mathrm{~cm}^{3}\right.$, Kishida Chemical Co., Ltd.) and charged into the isothermal region of the reactor. Before each test, diluted catalysts were sulfided according to the previous procedure ${ }^{25)}$. Diluted catalysts were sulfided with $5 \% \mathrm{H}_{2} \mathrm{~S}$ in $\mathrm{H}_{2}$ at $100{ }^{\circ} \mathrm{C}$ for $1 \mathrm{~h}, 200{ }^{\circ} \mathrm{C}$ for $1 \mathrm{~h}, 300{ }^{\circ} \mathrm{C}$ for $1 \mathrm{~h}$, and $400{ }^{\circ} \mathrm{C}$ for $3 \mathrm{~h}$. After activation of catalysts was finished, PFAD was pumped into the reactor. The pump instrument and piping were heated during the activity test with ribbon heaters due to the high melting point of the reactant. The reaction was conducted under $3 \mathrm{MPa}$ hydrogen pressure, with a liquid hourly space velocity (LHSV) of $1 \mathrm{~h}^{-1}, \mathrm{H}_{2} /$ feedstock ratio of $1000(\mathrm{~mL} / \mathrm{mL})$, and a temperature range of $300-350{ }^{\circ} \mathrm{C}$. The catalytic activity was measured after stabilization at approximately $3.5 \mathrm{~h}$. Gas and liquid samples were taken and analyzed by GC. The last three samples which showed stable GC data were collected, and the average of the results was taken. During the activity test, at least three samples were obtained at every reaction temperature, and the analysis was conducted in triplicate. All data were the average of three samples.

Product identification was performed using a gas chromatograph-mass spectrometer (GC-MS-QP5050A, Shimadzu Corp.) equipped with the same capillary column. Another gas chromatograph with a TCD and a Unibeads $C$ column (GL Sciences Inc., $3 \mathrm{~m} \times 3 \mathrm{~mm}$ i.d.) was used to measure the other components, such as $\mathrm{CO}$ and $\mathrm{CO}_{2}$, in the gaseous products. The conversion, selectivity, and yield were calculated using the following equations:

Conversion $[\mathrm{C} \%]=$
$\left(1-\frac{\text { Carbon atoms of unreacted in feedstock }[\mathrm{C} \mathrm{mol}]}{\text { Carbon atoms in feedstock }[\mathrm{C} \mathrm{mol}]}\right) \times 100$

Selectivity of component $\mathrm{i}[\mathrm{C} \%]=$

Carbon atoms in component $\mathrm{i}[\mathrm{C} \mathrm{mol}]$

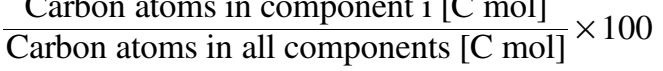

Yield of component i $[\mathrm{C} \%]=$

Conversion $[\mathrm{C} \%] \times$ Liquid selectivity of component i [C \%] 100

\section{Results}

\section{1. Catalyst Characterization}

3. 1. 1. Physical Properties of Catalysts

The physical properties of the catalysts are shown in Table 1. The surface area of the CoMo catalysts decreased with higher Co/Mo mole ratio, with $224 \mathrm{~m}^{2} / \mathrm{g}$ for $\mathrm{CoMo}(0.02) / \mathrm{Al}_{2} \mathrm{O}_{3}$, and $197 \mathrm{~m}^{2} / \mathrm{g}$ for $\mathrm{CoMo}(0.35) /$ $\mathrm{Al}_{2} \mathrm{O}_{3}$. All catalysts had a lower total pore volume and pore size distribution than $\mathrm{Al}_{2} \mathrm{O}_{3}$. TiO $\mathrm{TiO}_{2}$ coated $\mathrm{Al}_{2} \mathrm{O}_{3}$ supports had lower surface area than $\mathrm{Al}_{2} \mathrm{O}_{3}$, and the surface area decreased with higher $\mathrm{TiO}_{2}$ coating amount. Comparing $\mathrm{CoMo}(0.05) / \mathrm{Al}_{2} \mathrm{O}_{3}$ and $\mathrm{CoMo}(0.05) / \mathrm{Ti}^{-} \mathrm{Al}$ catalysts, the surface area decreased in the order of $\mathrm{CoMo}(0.05) / \mathrm{Al}_{2} \mathrm{O}_{3}\left(220 \mathrm{~m}^{2} / \mathrm{g}\right)>\mathrm{CoMo}(0.05) / \mathrm{Ti}(10)^{-}$ $\mathrm{Al}\left(191 \mathrm{~m}^{2} / \mathrm{g}\right)>\mathrm{CoMo}(0.05) / \mathrm{Ti}(15)-\mathrm{Al}\left(173 \mathrm{~m}^{2} / \mathrm{g}\right)>$ CoMo(0.05)/Ti(20)-Al $\left(163 \mathrm{~m}^{2} / \mathrm{g}\right)$. Therefore, the specific surface area of the supports decreased with higher loading of $\mathrm{TiO}_{2}$ onto $\mathrm{Al}_{2} \mathrm{O}_{3}$. The XRF results confirmed that all catalysts were prepared at the target Co/Mo ratio.

\section{1. 2. NO Chemisorption}

Pulse NO chemisorption showed that the adsorption amount of NO increased from 3.4 to $8.4 \mu \mathrm{mol} / \mathrm{g}$ with higher $\mathrm{Co} / \mathrm{Mo}$ mole ratio from 0.02 to 0.35 , due to the increase in the amount of CoMoS phase with higher Co content ${ }^{32), 33)}$. Pulse NO chemisorption also showed no difference in $\mathrm{NO}$ adsorption on $\mathrm{CoMo}(0.05) / \mathrm{Al}_{2} \mathrm{O}_{3}$ and $\mathrm{CoMo}(0.05) / \mathrm{Ti}(10)-\mathrm{Al}$. In contrast, NO adsorption amount increased from 5.3 to $8.0 \mu \mathrm{mol} / \mathrm{g}$ with the increase in amount of $\mathrm{TiO}_{2}$ coating from 10 to $15 \%$ and $20 \%$.

\section{1. 3. $\mathrm{H}_{2}$-TPR}

The $\mathrm{H}_{2}$-TPR patterns of various catalysts are shown in Fig. 1. The observed reduction peaks occurred mainly in two ranges from 150 to $400{ }^{\circ} \mathrm{C}$, and 400 to $600{ }^{\circ} \mathrm{C}$. The peak in the lower temperature range from 150 to $400{ }^{\circ} \mathrm{C}$ represents the consumption of $\mathrm{H}_{2}$, which reacts with the weak $\mathrm{H}-\mathrm{S}$ bond on the surface of the 
Table 1 Chemical Composition and Physical Properties of Catalysts

\begin{tabular}{|c|c|c|c|c|c|c|c|c|}
\hline \multirow[b]{2}{*}{ Catalyst } & \multicolumn{4}{|c|}{ Chemical composition ${ }^{\text {a) }}[\mathrm{wt} \%]$} & \multicolumn{4}{|c|}{ Parameter } \\
\hline & $\mathrm{CoO}$ & $\mathrm{MoO}_{3}$ & $\mathrm{TiO}_{2}$ & $\begin{array}{c}\text { Co/Mo ratio } \\
{[-]}\end{array}$ & $\begin{array}{l}S_{\mathrm{BET}}{ }^{\mathrm{b})} \\
{\left[\mathrm{m}^{2} / \mathrm{g}\right]}\end{array}$ & $\begin{array}{c}V_{\text {total }}{ }^{\mathrm{c})} \\
{\left[\mathrm{cm}^{3} / \mathrm{g}\right]}\end{array}$ & $\begin{array}{l}d_{\mathrm{avg}}{ }^{\mathrm{c})} \\
{[\mathrm{nm}]}\end{array}$ & $\begin{array}{c}\text { NO uptake }{ }^{\mathrm{d})} \\
{[\mu \mathrm{mol} / \mathrm{g}]}\end{array}$ \\
\hline $\mathrm{Al}_{2} \mathrm{O}_{3}$ & - & - & - & - & 260 & 0.726 & 11.3 & - \\
\hline $\mathrm{Ti}(10)-\mathrm{Al}$ & - & - & 8.46 & - & 228 & 0.689 & 12.1 & - \\
\hline $\mathrm{Ti}(15)-\mathrm{Al}$ & - & - & 14.1 & - & 209 & 0.624 & 11.8 & - \\
\hline $\mathrm{Ti}(20)-\mathrm{Al}$ & - & - & 17.5 & - & 199 & 0.656 & 10.6 & - \\
\hline $\mathrm{Mo} / \mathrm{Al}_{2} \mathrm{O}_{3}$ & - & 21.7 & - & - & 220 & 0.512 & 9.25 & - \\
\hline $\mathrm{CoMo}(0.02) / \mathrm{Al}_{2} \mathrm{O}_{3}$ & 0.247 & 20.3 & - & 0.0233 & 224 & 0.524 & 9.36 & 3.4 \\
\hline $\mathrm{CoMo}(0.05) / \mathrm{Al}_{2} \mathrm{O}_{3}$ & 0.521 & 20.5 & - & 0.0487 & 220 & 0.479 & 10.6 & 5.4 \\
\hline $\mathrm{CoMo}(0.1) / \mathrm{Al}_{2} \mathrm{O}_{3}$ & 1.08 & 19.3 & - & 0.108 & 218 & 0.518 & 9.29 & 7.3 \\
\hline $\mathrm{CoMo}(0.35) / \mathrm{Al}_{2} \mathrm{O}_{3}$ & 3.68 & 18.8 & - & 0.378 & 197 & 0.619 & 10.9 & 8.4 \\
\hline $\mathrm{CoMo}(0.05) / \mathrm{Ti}(10)-\mathrm{Al}$ & 0.541 & 19.9 & - & 0.0516 & 191 & 0.538 & 16.0 & 5.3 \\
\hline $\mathrm{CoMo}(0.05) / \operatorname{Ti}(15)-\mathrm{Al}$ & 0.542 & 20.1 & - & 0.0512 & 173 & 0.536 & 13.9 & 6.5 \\
\hline $\mathrm{CoMo}(0.05) / \mathrm{Ti}(20)-\mathrm{Al}$ & 0.504 & 19.5 & - & 0.0490 & 163 & 0.451 & 8.06 & 8.0 \\
\hline
\end{tabular}

a) Chemical composition was measured by XRF.

b) Specific surface area calculated by the BET method.

c) Total pore volume and pore size distribution calculated by the $\mathrm{BJH}$ model.

d) Amount of adsorbed NO measured by pulse chemisorption at $40{ }^{\circ} \mathrm{C}$.

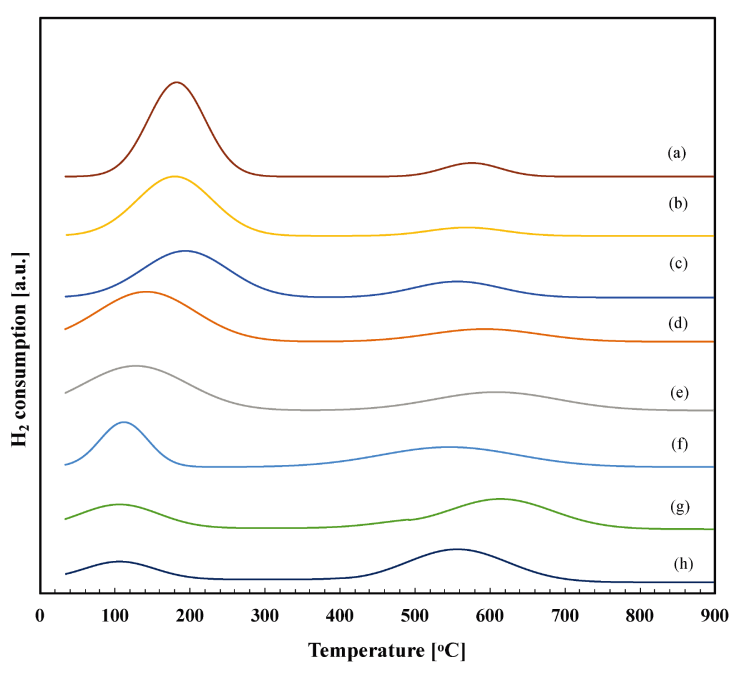

Fig. $1 \mathrm{H}_{2}$-TPR Patterns of Various Catalysts; (a) $\mathrm{Mo} / \mathrm{Al}_{2} \mathrm{O}_{3}$, (b) $\mathrm{CoMo}(0.02) / \mathrm{Al}_{2} \mathrm{O}_{3}$, (c) $\mathrm{CoMo}(0.05) / \mathrm{Al}_{2} \mathrm{O}_{3}$, (d) $\mathrm{CoMo}(0.1) /$ $\mathrm{Al}_{2} \mathrm{O}_{3}$, (e) $\mathrm{CoMo}(0.35) / \mathrm{Al}_{2} \mathrm{O}_{3}$, (f) $\mathrm{CoMo}(0.05) / \mathrm{Ti}(10)-\mathrm{Al}$, (g) $\mathrm{CoMo}(0.05) / \mathrm{Ti}(15)-\mathrm{Al}$, and (h) $\mathrm{CoMo}(0.05) / \mathrm{Ti}(20)-\mathrm{Al}$

catalyst in the recombination of $\mathrm{H}_{2} \mathrm{~S}^{15)}$. The peak in the higher temperature range from 400 to $600{ }^{\circ} \mathrm{C}$ was assigned to the consumption of $\mathrm{H}_{2}$ in the reduction of CoMoS and $\mathrm{MoS}_{2}$, or CoMoS, TiMoS, and $\mathrm{MoS}_{2}$ to form an active site (sulfur vacancy) in the case of $\mathrm{TiO}_{2}$ free and $\mathrm{TiO}_{2}$-coated catalysts, respectively ${ }^{15)}$. For catalysts with $\mathrm{Co} / \mathrm{Mo}$ mole ratio up to 0.05 , the reduction temperature in the higher temperature range decreased, and for catalysts with higher mole ratios, the reduction temperature in the higher temperature range increased. The reduction temperature in the higher temperature range increased more for $\operatorname{CoMo}(0.05) /$ $\mathrm{Ti}(15)-\mathrm{Al}$ than for $\mathrm{TiO}_{2}$-free catalysts, but the reduction temperature decreased for $\mathrm{CoMo}(0.05) / \mathrm{Ti}(10)-\mathrm{Al}$ and
$\mathrm{CoMo}(0.05) / \mathrm{Ti}(20)-\mathrm{Al}$ catalysts.

\section{2. HDO of Palm Fatty Acid Distillate \\ 3. 2. 1. Hydrotreating Reaction on $\mathrm{Mo} / \mathrm{Al}_{2} \mathrm{O}_{3}$ and $\mathrm{CoMo}(0.35) / \mathrm{Al}_{2} \mathrm{O}_{3}$ \\ The detailed results of the activity tests over Mo/} $\mathrm{Al}_{2} \mathrm{O}_{3}$ and $\mathrm{CoMo}(0.35) / \mathrm{Al}_{2} \mathrm{O}_{3}$ catalysts are shown in Tables A-2 and A-6. The composition of the product was similar for all $\mathrm{HDO}$ reactions. $\mathrm{CO}, \mathrm{CO}_{2}$ and $\mathrm{C}_{3} \mathrm{H}_{8}$ were produced, at $0.49,1.43$ and $0.22 \%$, respectively, and $\mathrm{C} 1, \mathrm{C} 2$ and $\mathrm{C} 4$ hydrocarbons were produced in trace amounts over $\mathrm{Mo} / \mathrm{Al}_{2} \mathrm{O}_{3}$ at $350{ }^{\circ} \mathrm{C}$. $\mathrm{Mo} / \mathrm{Al}_{2} \mathrm{O}_{3}$ and $\mathrm{CoMo}(0.35) / \mathrm{Al}_{2} \mathrm{O}_{3}$ formed similar products. Liquid products formed clear and colorless oil and water phases at reaction temperatures higher than $325^{\circ} \mathrm{C}$. In contrast, the liquid products became cloudy and contained a suspension of white crystals at reaction temperatures lower than $325^{\circ} \mathrm{C}$, indicating that as the catalysts were inactive, the liquid products became cloudy and contained the white crystals. The oil phase, considered to contain liquid hydrocarbon products, was separated and analyzed using the GC-MS. The gas chromatograph with hydrogen-flame ionization detector (GC-FID) analysis showed that the liquid hydrocarbon products were a simple mixture containing mainly $n$-paraffins of C15-18 (86.6\%). The liquid hydrocarbon products also contained alkanes of C4-14 (2.74\%) and isomers of C15-18 (2.39\%), with trace amounts of olefin of C15-18 (1.26\%). Some oxygenates (e.g., fatty acid, fatty alcohol, monoglycerides, diglycerides and long-chain ester) were also contained in the $\mathrm{C} 18+$ fraction. $\mathrm{Mo} / \mathrm{Al}_{2} \mathrm{O}_{3}$ and $\mathrm{CoMo}(0.35) / \mathrm{Al}_{2} \mathrm{O}_{3}$ showed similarly high PFAD conversion of more than $99 \%$ at all reaction temperatures. Selectivity for oxygenated compounds decreased from 2.9 to $1.0 \%$ at $300{ }^{\circ} \mathrm{C}$ and from 2.6 to $1.1 \%$ at $325{ }^{\circ} \mathrm{C}$ over $\mathrm{CoMo}(0.35) / \mathrm{Al}_{2} \mathrm{O}_{3}$ compared to $\mathrm{Mo} / \mathrm{Al}_{2} \mathrm{O}_{3}$, showing the highest deoxygen- 
ation activity. Selectivity for oxygenated compounds was $4.32 \%$ at $275{ }^{\circ} \mathrm{C}$ for $\mathrm{CoMo}(0.35) / \mathrm{Al}_{2} \mathrm{O}_{3}$ (Table A-6), which is higher than $2.61 \%$ at $300{ }^{\circ} \mathrm{C}$ for the $\mathrm{Mo} /$ $\mathrm{Al}_{2} \mathrm{O}_{3}$ (Table A-2), indicating that the reaction temperature should be above $300{ }^{\circ} \mathrm{C}$, consistent with the results of the previous study. Sulfided CoMo catalysts showed poor performance in comparison with the sulfided Mo catalyst at reaction temperature $280{ }^{\circ} \mathrm{C}^{28}$. This is because the higher synergy between Co and Mo can be expected at reaction temperatures higher than $280{ }^{\circ} \mathrm{C}$. In addition, all catalysts showed low cracking reactant selectivity of less than $3 \%$ at all reaction temperatures. The selectivity for $n-\mathrm{C}_{16}+n-\mathrm{C}_{18}$ was $77.9 \%$ at $300{ }^{\circ} \mathrm{C}$ (Table A-6) for $\mathrm{CoMo}(0.35) / \mathrm{Al}_{2} \mathrm{O}_{3}$, which is higher than the selectivity at $275^{\circ} \mathrm{C}$, indicating that the reaction temperature of $300{ }^{\circ} \mathrm{C}$ is desirable. In addition, formation of olefins was suppressed by the loading of Co as a promoter. However, the promoter (Co) had no effect on the cracking reaction. Selectivity for the isomerization reaction was high at $13.0 \%$ over $\mathrm{CoMo}(0.35) / \mathrm{Al}_{2} \mathrm{O}_{3}$ at a reaction temperature of $275{ }^{\circ} \mathrm{C}$ (Table A-6), but the same low value as that of $\mathrm{Mo} / \mathrm{Al}_{2} \mathrm{O}_{3}$ was observed at reaction temperatures of

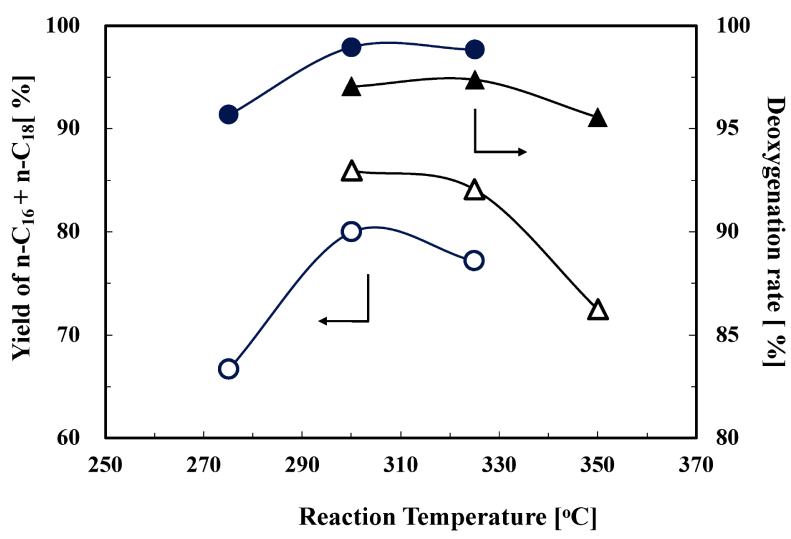

Fig. 2 Yields of $n-\mathrm{C}_{16}+n-\mathrm{C}_{18}$ (solid symbols) and Deoxygenation Rate (open symbols) over $\mathrm{Mo} / \mathrm{Al}_{2} \mathrm{O}_{3}$ (triangles) and $\mathrm{CoMo}(0.35) / \mathrm{Al}_{2} \mathrm{O}_{3}$ (circles)
$300{ }^{\circ} \mathrm{C}$ and $325{ }^{\circ} \mathrm{C}$. The yields of $n-\mathrm{C}_{16}+n-\mathrm{C}_{18}$, which are produced through the HDO reaction, and deoxygenation rates of $\mathrm{Mo} / \mathrm{Al}_{2} \mathrm{O}_{3}$ and $\mathrm{CoMo}(0.35) / \mathrm{Al}_{2} \mathrm{O}_{3}$ are compared in Fig. 2. $\mathrm{Mo} / \mathrm{Al}_{2} \mathrm{O}_{3}$, showed higher yield of $n-\mathrm{C}_{16}+n-\mathrm{C}_{18}$, whereas $\mathrm{CoMo}(0.35) / \mathrm{Al}_{2} \mathrm{O}_{3}$ showed higher deoxygenation rate, indicating that the addition of Co improves the activity but reduces the yield of $n-\mathrm{C}_{16}+n-\mathrm{C}_{18}$.

\section{2. 2. Hydrotreating Reaction over $\mathrm{CoMo} / \mathrm{Al}_{2} \mathrm{O}_{3}$ Catalysts with Different Co/Mo Ratios}

The activity test results of all $\mathrm{CoMo} / \mathrm{Al}_{2} \mathrm{O}_{3}$ catalysts at reaction temperatures $300{ }^{\circ} \mathrm{C}$ and $325^{\circ} \mathrm{C}$ are shown in Table 2. Detailed results are shown in Tables A-2 to A-6. For all $\mathrm{CoMo} / \mathrm{Al}_{2} \mathrm{O}_{3}$ catalysts, the isomerization yield was significantly low at reaction temperatures above $300{ }^{\circ} \mathrm{C}$ and was below approximately $3 \%$ in all tests. Conversion over $\mathrm{Mo} / \mathrm{Al}_{2} \mathrm{O}_{3}$ and $\mathrm{CoMo} /$ $\mathrm{Al}_{2} \mathrm{O}_{3}$ catalysts was more than $99 \%$ at all reaction temperatures. In addition, $\mathrm{CoMo}(0.05) / \mathrm{Al}_{2} \mathrm{O}_{3}$ and $\mathrm{CoMo}(0.35) / \mathrm{Al}_{2} \mathrm{O}_{3}$ showed lower oxygenated yield than $\mathrm{Mo} / \mathrm{Al}_{2} \mathrm{O}_{3}$. $\mathrm{CoMo}(0.05) / \mathrm{Al}_{2} \mathrm{O}_{3}$ gave a slightly higher yield of $n-\mathrm{C}_{16}$ and $n-\mathrm{C}_{18}$ than $\mathrm{Mo} / \mathrm{Al}_{2} \mathrm{O}_{3}$ at $300{ }^{\circ} \mathrm{C}$ $(87.1 \%)$. Basically, the yield over the Co-containing catalysts showed no significant change compared to the $\mathrm{Mo} / \mathrm{Al}_{2} \mathrm{O}_{3}$ catalysts. However, $\mathrm{CoMo}(0.35) / \mathrm{Al}_{2} \mathrm{O}_{3}$ formed higher yields of $n-\mathrm{C}_{15}$ and $n-\mathrm{C}_{17}$, and lower yields of $n-\mathrm{C}_{16}$ and $n-\mathrm{C}_{18}$ than $\mathrm{Mo} / \mathrm{Al}_{2} \mathrm{O}_{3}$ at all reaction temperatures. Selectivity for $\mathrm{CO}$ and $\mathrm{CO}_{2}$ over $\mathrm{CoMo}$ / $\mathrm{Al}_{2} \mathrm{O}_{3}$ catalysts was about twice as high as $\mathrm{Mo} / \mathrm{Al}_{2} \mathrm{O}_{3}$, and the selectivity increased with higher reaction temperature, but remained lower than $4 \%$ at all reaction temperatures.

\section{2. 3. Hydrotreating Reaction over CoMo/Ti-Al Catalysts}

To elucidate the influence of $\mathrm{TiO}_{2}-\mathrm{Al}_{2} \mathrm{O}_{3}$, HDO reactions of PFAD over various sulfided $\mathrm{CoMo} / \mathrm{Ti}^{-} \mathrm{Al}$ catalysts with different $\mathrm{TiO}_{2}$ coating amounts were carried out under the following reaction conditions: $T=275$ $325{ }^{\circ} \mathrm{C}$, WHSV $=1 \mathrm{~h}^{-1}, P=3 \mathrm{MPa}$, and $\mathrm{H}_{2} /$ feed $=$ $1000 \mathrm{~mL} / \mathrm{mL}$, as shown in Table 3. The yields of oxygenates compounds show that $\mathrm{TiO}_{2}$ coating did not

Table 2 Conversion and Several Yields over Sulfided Mo-based Catalysts for Hydrotreating of PFAD

\begin{tabular}{|c|c|c|c|c|c|c|c|c|c|c|}
\hline & \multicolumn{2}{|c|}{$\mathrm{Mo} / \mathrm{Al}_{2} \mathrm{O}_{3}$} & \multicolumn{2}{|c|}{$\mathrm{CoMo}(0.02) / \mathrm{Al}_{2} \mathrm{O}_{3}$} & \multicolumn{2}{|c|}{$\mathrm{CoMo}(0.05) / \mathrm{Al}_{2} \mathrm{O}_{3}$} & \multicolumn{2}{|c|}{$\mathrm{CoMo}(0.1) / \mathrm{Al}_{2} \mathrm{O}_{3}$} & \multicolumn{2}{|c|}{$\mathrm{CoMo}(0.35) / \mathrm{Al}_{2} \mathrm{O}_{3}$} \\
\hline Conversion & 99.5 & 99.5 & 99.4 & 99.5 & 99.5 & 99.5 & 99.3 & 99.5 & 100 & 100 \\
\hline \multicolumn{11}{|l|}{ Yields [\%] } \\
\hline$<\mathrm{C}_{14}$ & 1.7 & 2.0 & 2.0 & 2.4 & 1.7 & 1.9 & 1.9 & 2.3 & 2.4 & 2.6 \\
\hline$i-\mathrm{C}_{15-18}$ & 1.4 & 1.5 & 1.6 & 2.0 & 0.9 & 1.2 & 1.3 & 1.6 & 0.6 & 0.6 \\
\hline$n-\mathrm{C}_{16}+n-\mathrm{C}_{18}$ & 85.9 & 84.1 & 85.8 & 82.5 & 87.1 & 84.4 & 83.1 & 81.1 & 79.9 & 77.2 \\
\hline Oxygenates ${ }^{\text {b) }}$ & 3.0 & 2.6 & 3.4 & 2.6 & 1.9 & 2.4 & 3.4 & 2.4 & 1.1 & 1.2 \\
\hline
\end{tabular}

a) Reaction temperature $\left({ }^{\circ} \mathrm{C}\right)$.

b) Oxygenates represent the total selectivity for alcohol, aldehyde, and ester. 
Table 3 Conversion and Several Yields over $\mathrm{TiO}_{2}$ Coated Sulfided Catalysts for Hydrotreating of PFAD

\begin{tabular}{|c|c|c|c|c|c|c|c|c|c|}
\hline & \multicolumn{3}{|c|}{$\mathrm{CoMo}(0.05) / \mathrm{Ti}(10)-\mathrm{Al}$} & \multicolumn{3}{|c|}{$\mathrm{CoMo}(0.05) / \mathrm{Ti}(15)-\mathrm{Al}$} & \multicolumn{3}{|c|}{$\mathrm{CoMo}(0.05) / \mathrm{Ti}(20)-\mathrm{Al}$} \\
\hline & $275^{\text {a) }}$ & $300^{\mathrm{a})}$ & $325^{\mathrm{a})}$ & $275^{\text {a) }}$ & $300^{\mathrm{a})}$ & $325^{\mathrm{a})}$ & $275^{\mathrm{a})}$ & $300^{\mathrm{a})}$ & $325^{\mathrm{a}}$ \\
\hline Conversion & 97.8 & 99.2 & 99.7 & 96.8 & 99.1 & 99.7 & 97.6 & 99.7 & 99.7 \\
\hline \multicolumn{10}{|l|}{ Selectivity [\%] } \\
\hline$<\mathrm{C}_{14}$ & 2.3 & 2.7 & 3.0 & 2.0 & 2.4 & 2.3 & 2.2 & 2.2 & 2.3 \\
\hline$i-\mathrm{C}_{15-18}$ & 1.6 & 1.8 & 2.4 & 1.3 & 1.2 & 1.7 & 1.7 & 1.6 & 2.2 \\
\hline olefin- $\mathrm{C}_{15-18}$ & 6.4 & 4.0 & 0.4 & 8.5 & 1.4 & 1.3 & 5.1 & 1.2 & 1.3 \\
\hline$n-\mathrm{C}_{15}+n-\mathrm{C}_{17}$ & 1.8 & 3.9 & 7.1 & 1.9 & 4.1 & 7.3 & 2.0 & 3.5 & 6.1 \\
\hline$n-\mathrm{C}_{16}+n-\mathrm{C}_{18}$ & 60.7 & 81.5 & 83.6 & 68.4 & 86.9 & 84.3 & 72.1 & 88.0 & 84.9 \\
\hline Oxygenates $^{\text {b) }}$ & 25.0 & 5.3 & 3.2 & 14.6 & 3.3 & 2.8 & 14.7 & 3.6 & 3.1 \\
\hline
\end{tabular}

a) Reaction temperature $\left({ }^{\circ} \mathrm{C}\right)$.

b) Oxygenates represent the total selectivity for alcohol, aldehyde, and ester.

change the catalytic activity but decreased the deoxygenation activity at all reaction temperatures. Especially at $275{ }^{\circ} \mathrm{C}$ in the low-temperature range, all $\mathrm{CoMo} / \mathrm{Ti}-\mathrm{Al}$ catalysts achieved high olefin yield with oxygenates yield of more than $5 \%$. Comparing $\mathrm{CoMo}(0.05) / \mathrm{Ti}(10)-\mathrm{Al}$ with $\mathrm{CoMo}(0.05) / \mathrm{Ti}(15)-\mathrm{Al}$ and $\mathrm{CoMo}(0.05) / \mathrm{Ti}(20)-\mathrm{Al}, \mathrm{CoMo}(0.05) / \mathrm{Ti}(10)-\mathrm{Al}$ showed higher yield for oxygenates compounds at all reaction temperatures, which implies lower deoxygenation activity. The yield of $n-\mathrm{C}_{16}$ and $n$ - $\mathrm{C}_{18}$ increased with higher amount of $\mathrm{TiO}_{2}$ coating from 10 to $20 \%$ for all reaction temperatures. In addition, $\mathrm{CoMo}(0.05) / \mathrm{Ti}(20)-\mathrm{Al}$ showed slightly higher yield $88.0 \%$ than $\mathrm{CoMo}(0.05) /$ $\mathrm{Al}_{2} \mathrm{O}_{3}$ catalyst at $300{ }^{\circ} \mathrm{C}$. The three $\mathrm{TiO}_{2}$ coated catalysts showed low cracking yield of less than $5 \%$ at all reaction temperatures. Comparing $\mathrm{CoMo}(0.05) / \mathrm{Al}_{2} \mathrm{O}_{3}$ with the three $\mathrm{TiO}_{2}$-coated catalysts, $\mathrm{CoMo}(0.05) /$ Ti(20)-Al showed $n-\mathrm{C}_{15}+n-\mathrm{C}_{17}$ yields of $3.5 \%$ and $6.1 \%$ whereas $\mathrm{CoMo}(0.05) / \mathrm{Al}_{2} \mathrm{O}_{3}$ showed $5.3 \%$ and $8.8 \%$ at reaction temperatures of $300{ }^{\circ} \mathrm{C}$ and $325{ }^{\circ} \mathrm{C}$, respectively, which indicates that $\mathrm{DCO}$ yield was suppressed by coating of $\mathrm{TiO}_{2}$. $\quad \mathrm{All} \mathrm{TiO}_{2}$ coated catalysts showed low isomerization yield of less than $2 \%$ at all reaction temperatures, except for $\mathrm{CoMo}(0.05) / \mathrm{Ti}(10)^{-}$ $\mathrm{Al}$ at $325{ }^{\circ} \mathrm{C}(2.4 \%)$ and $\mathrm{CoMo}(0.05) / \mathrm{Ti}(20)-\mathrm{Al}$ at $325{ }^{\circ} \mathrm{C}(2.2 \%)$.

\section{Discussion}

\section{1. Hydrotreating of PFAD over Sulfided CoMo Catalysts}

Based on the activity test results, the hydrogenation of PFAD mainly produced two types of liquid products, oxygenate compounds such as aldehydes, alcohols, and esters, and hydrocarbons, including normal hydrocarbons, isomers, and cracking products (light hydrocarbons) as found by previous studies of reduced $\mathrm{Pt}-\mathrm{Sn}$ catalyst ${ }^{2}$. $\quad \mathrm{TiO}_{2}$ free and $\mathrm{TiO}_{2}$ coated CoMo catalysts produced oxygenate compounds such as aldehydes, alcohols, and ester, in excellent agreement with the previous study ${ }^{2}$. Among the liquid hydrocarbons, $n$ - $\mathrm{C}_{15} \sim$ $n-\mathrm{C}_{18}$ were the main components with high yields. For all catalysts with high deoxygenation activity, the yields of $n-\mathrm{C}_{16}$ and $n-\mathrm{C}_{18}$ decreased and the yields of $n-\mathrm{C}_{15}$ and $n-\mathrm{C}_{17}$ increased with higher reaction temperature. As with PtSn catalysts, fatty acids were transformed into 1-hexadecanol and 1-octadecanol via HDO and $n-\mathrm{C}_{15}$ and $n-\mathrm{C}_{17}$ hydrocarbons via decarboxylation/decarbonylation. Then, 1-hexadecanol and octadecyl alcohol were converted to $n-\mathrm{C}_{16}$ and $n-\mathrm{C}_{18}$ as the HDO reaction progressed further. In addition, the isomerization yield also increased slightly with higher reaction temperature. However, the $\mathrm{Mo} / \mathrm{Al}_{2} \mathrm{O}_{3}$ based catalysts caused little isomerization and cracking products because the catalyst surface has almost non-existent $\mathrm{Br} \varnothing n$ sted acid sites ${ }^{30)}$. Consequently, $\mathrm{Mo} / \mathrm{Al}_{2} \mathrm{O}_{3}$ based catalysts showed higher yield of $n-\mathrm{C}_{16}$ and $n$ - $\mathrm{C}_{18}$ than PtSn catalysts, consistent with the results of previous studies $^{2,7)}$.

\section{2. Addition Effect of Co}

Co was added to $\mathrm{Mo} / \mathrm{Al}_{2} \mathrm{O}_{3}$ as a promoter and activity tests were carried out to investigate the effect of Co addition. $\mathrm{Mo} / \mathrm{Al}_{2} \mathrm{O}_{3}$ showed high deoxygenation activity with the yield of oxygenates below $5 \%$ at all reaction temperatures, whereas Co loaded $\mathrm{Mo} / \mathrm{Al}_{2} \mathrm{O}_{3}$ showed slightly improved deoxygenation. Addition of Co promoter to the $\mathrm{MoS}_{2}$ phase clearly affects the mechanism and kinetics of reconstruction of the active phases ${ }^{30,35)-37 \text {. }}$. Co prefers the sulfur edge and forms Co-S-Mo phases with high activity ${ }^{29,33), 36)}$. $\mathrm{CoMo}(0.35) / \mathrm{Al}_{2} \mathrm{O}_{3}$ showed higher deoxygenation activity, but lower yield of $n$ - $\mathrm{C}_{16}$ $+n-\mathrm{C}_{18}$ and higher yield of $n-\mathrm{C}_{15}+n-\mathrm{C}_{17}$ than $\mathrm{Mo} /$ $\mathrm{Al}_{2} \mathrm{O}_{3}$. This is because $\mathrm{MoS}_{2}$ has a sulfur vacancy, which promotes the HDO reaction ${ }^{29)}$. Then, a series of $\mathrm{CoMo} / \mathrm{Al}_{2} \mathrm{O}_{3}$ catalysts with different Co to Mo ratios were prepared to confirm the effect of the Co/Mo ratio. The changes in yield of $n-\mathrm{C}_{16}+n-\mathrm{C}_{18}$ and $n-\mathrm{C}_{15}+n-\mathrm{C}_{17}$ with $\mathrm{Co} / \mathrm{Mo}$ ratio are shown in Fig. 3. The maximum yields of $n-\mathrm{C}_{16}$ and $n-\mathrm{C}_{18}$ were observed at $\mathrm{Co} / \mathrm{Mo}=$ $0.05(87.1 \%)$ for the $\mathrm{CoMo} / \mathrm{Al}_{2} \mathrm{O}_{3}$ series, and the yield of $n-\mathrm{C}_{15}$ and $n-\mathrm{C}_{17}$ increased with $\mathrm{Co} / \mathrm{Mo}>0.05$. The reason for this tendency is the presence of CoMoS. The adsorbed amount of NO increased because CoMoS was increased with the higher loading of Co as shown 


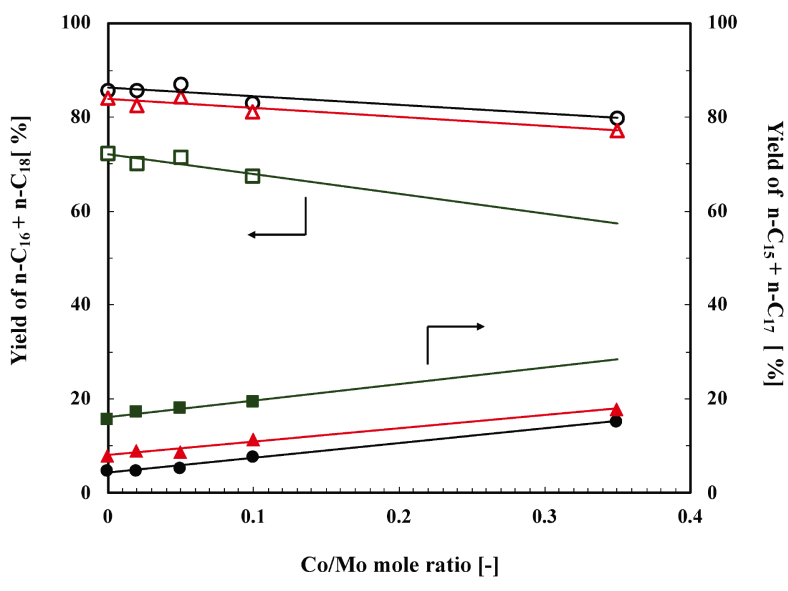

Reaction conditions: $P=3 \mathrm{MPa}$, LHSV $=1 \mathrm{~h}^{-1}, \mathrm{H}_{2} /$ feed $=1000(\mathrm{v} / \mathrm{v})$. Reaction temperature: $300{ }^{\circ} \mathrm{C}$ (circles), $325^{\circ} \mathrm{C}$ (triangles), $350{ }^{\circ} \mathrm{C}$ (squares).

Fig. 3 Effect of Co/Mo Ratio on Yields of $n-\mathrm{C}_{16}+n-\mathrm{C}_{18}$ (open symbols) and $n-\mathrm{C}_{15}+n-\mathrm{C}_{17}$ (solid symbols)

in Table 1. As the mole ratio of $\mathrm{Co} / \mathrm{Mo}$ increased from 0.02 to 0.35 , the amount of NO adsorbed increased from 3.4 to $8.4 \mathrm{mmol} / \mathrm{g}$, indicating higher CoMoS phase content. Co promotes the activity of the hydrodesulfurization (HDS) reaction remarkably ${ }^{27}$. On the other hand, the CoMoS phase has two different adsorption phases for the hydrotreating of PFAD. CoMoS catalyst has HDO activity due to its sulfur vacancy structure, and saturated edge site under hydrogenation conditions, which enabled $\mathrm{C}-\mathrm{C}$ hydrogenoly$\mathrm{sis}^{34)}$. The DCO route involves hydrogenation of the hydroxyl group and hydrogenolysis of the $\mathrm{C}-\mathrm{C}$ bond adjacent to the carbonyl group $(\mathrm{C}-\mathrm{C}(=\mathrm{O}))$ to yield hydrocarbons with one fewer carbon and $\mathrm{CO}$. Cleavage of the $\mathrm{C}-\mathrm{C}$ bond can occur through a basic attack on the hydrogen atom in the $\beta$-position because the carbon atom carries a positive charge of the cationic intermediate over the Co-promoted catalysts and the final product should be CO. The basic site could be a sulfur anion $\left(\mathrm{S}^{2-}\right)$ species adjacent to the sulfur vacancy ${ }^{35)}$. Moreover, Co can increase the electron density of sulfur atoms ${ }^{36)}$, which would explain the promotion effect of Co on the DCO route. Therefore, the CoMoS phase has both HDO and DCO activity. Therefore, the amount of Co loading should be controlled to improve the catalyst activity but inhibit the DCO reaction, and the $\mathrm{Co} / \mathrm{Mo}$ mole ratio of 0.05 is the optimum for this reaction. The reaction pathways over the sulfided $\mathrm{CoMo} / \mathrm{Al}_{2} \mathrm{O}_{3}$ are presented in Scheme 1 .

\section{3. Coating Effect of $\mathrm{TiO}_{2}$}

CoMo supported on $\mathrm{TiO}_{2}$ coated $\mathrm{Al}_{2} \mathrm{O}_{3}$ (10-20 wt \%) was prepared for evaluating the effect of $\mathrm{TiO}_{2}$ coating. The metal loading ratio was set to 0.05 , which showed high activity at low temperature $\left(300{ }^{\circ} \mathrm{C}\right)$ and high HDO yield $\left(n-\mathrm{C}_{16}+n-\mathrm{C}_{18}\right)$. The yields of $n-\mathrm{C}_{16}+$

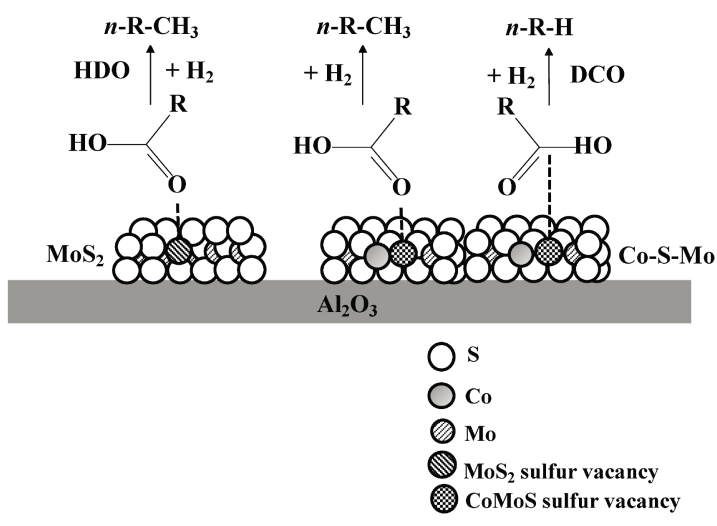

Scheme 1 Proposed Mechanism of Hydrogenation of PFAD over $\mathrm{CoMo} / \mathrm{Al}_{2} \mathrm{O}_{3}$ Catalysts ( $\mathrm{R}$ : $\mathrm{C}_{15} \mathrm{H}_{31}$ and $\mathrm{C}_{17} \mathrm{H}_{35}$ ).

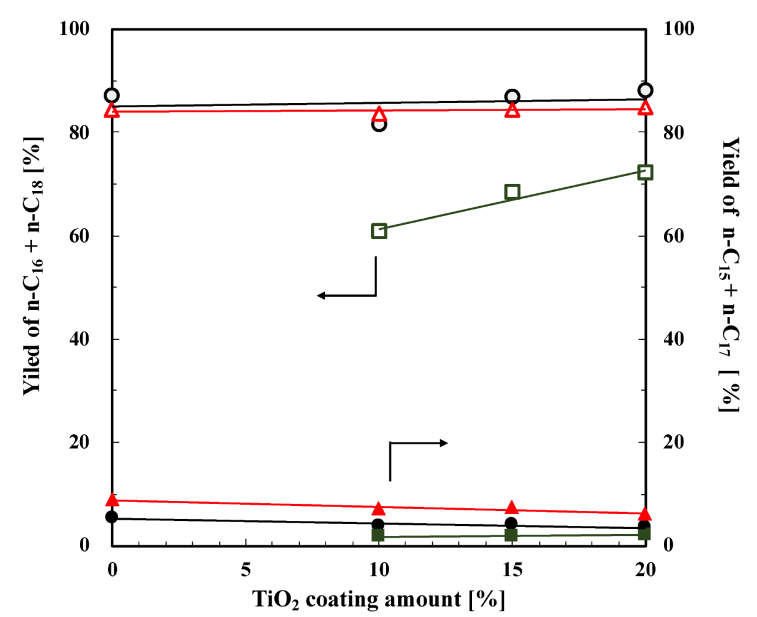

Reaction conditions: $P=3 \mathrm{MPa}$, LHSV $=1 \mathrm{~h}^{-1}, \mathrm{H}_{2} /$ feed $=1000(\mathrm{v} / \mathrm{v})$. Reaction temperature: $275{ }^{\circ} \mathrm{C}$ (squares), $300{ }^{\circ} \mathrm{C}$ (circles), $325{ }^{\circ} \mathrm{C}$ (triangles).

Fig. 4 Effect of $\mathrm{TiO}_{2}$ Coating on Yield of $n-\mathrm{C}_{16}+n-\mathrm{C}_{18}$ (open symbols) and $n-\mathrm{C}_{15}+n-\mathrm{C}_{17}$ (solid symbols)

$n-\mathrm{C}_{18}$ and $n-\mathrm{C}_{15}+n-\mathrm{C}_{17}$ over $\mathrm{CoMo}(0.05) / \mathrm{Al}_{2} \mathrm{O}_{3}$ and $\mathrm{TiO}_{2}$ coated catalysts are shown in Fig. 4. The $\mathrm{TiO}_{2}$-coated catalyst at $275^{\circ} \mathrm{C}$ (Table 3 ) showed no increase in activity due to the high yield for oxygenated compounds. On the other hand, the yield of $n-\mathrm{C}_{16}+$ $n-\mathrm{C}_{18}$ increased with higher amount of $\mathrm{TiO}_{2}$ coating. $\mathrm{CoMo}(0.05) / \mathrm{Ti}(20)-\mathrm{Al}$ showed the highest yield of $n-\mathrm{C}_{16}+n-\mathrm{C}_{18}(88.0 \%)$ among the catalysts with CoMo supported on $\mathrm{TiO}_{2}$ coated $\mathrm{Al}_{2} \mathrm{O}_{3}$. All $\mathrm{TiO}_{2}$-coating catalysts showed lower DCO yields than CoMo(0.05)/ $\mathrm{Al}_{2} \mathrm{O}_{3}$, and $\mathrm{CoMo}(0.05) / \mathrm{Ti}(20)-\mathrm{Al}$ showed the lowest DCO yield $(3.5 \%)$ at $300{ }^{\circ} \mathrm{C} . \quad \mathrm{H}_{2}$-TPR (Fig. 1) showed that the increase in the amount of $\mathrm{TiO}_{2}$ coating increased the reduction temperature to a higher range. Comparing $\mathrm{CoMo}(0.05) / \mathrm{Al}_{2} \mathrm{O}_{3}$ and $\mathrm{CoMo}(0.05) / \mathrm{Ti}(15)^{-}$ $\mathrm{Al}$, the latter peak of $\mathrm{CoMo}(0.05) / \mathrm{Ti}(15)-\mathrm{Al}_{2} \mathrm{O}_{3}$ was about $80{ }^{\circ} \mathrm{C}$ higher, which hinders the reduction of Mobased active phases. On the other hand, comparing 


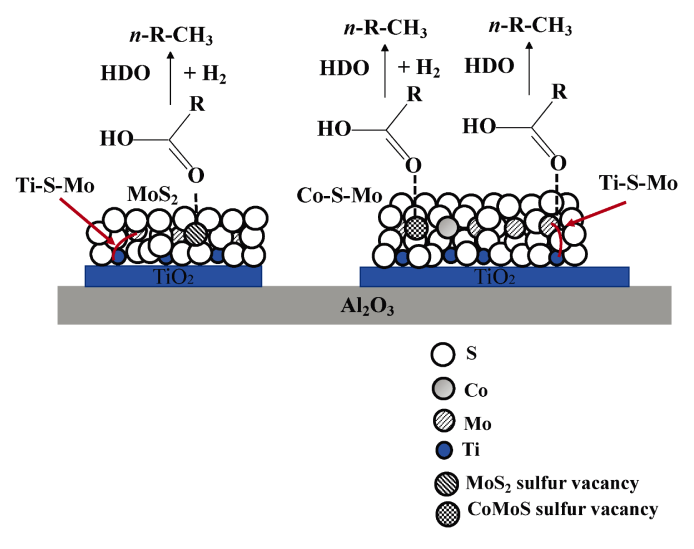

Scheme 2 Proposed Mechanism of Hydrogenation of PFAD over $\mathrm{CoMo} / \mathrm{Ti}-\mathrm{Al}_{2} \mathrm{O}_{3}$ Catalysts $\left(\mathrm{R}: \mathrm{C}_{15} \mathrm{H}_{31}\right.$ and $\left.\mathrm{C}_{17} \mathrm{H}_{35}\right)$

$\mathrm{CoMo}(0.05) / \mathrm{Al}_{2} \mathrm{O}_{3}$ and $\mathrm{CoMo}(0.05) / \mathrm{Ti}(20)-\mathrm{Al}$, the latter reduction peak of $\mathrm{CoMo}(0.05) / \mathrm{Ti}(20)-\mathrm{Al}$ was almost the same, which indicates that the active phase is efficiently formed if the $\mathrm{TiO}_{2}$ loading exceeds a certain percentage. This is because $\mathrm{TiO}_{2}$ coating enhances reduction of active metals and the formation of the CoMoS active phase ${ }^{14)}$. In addition, $\mathrm{TiO}_{2}$ coating formed the new active phase TiMoS. The effect of $\mathrm{TiO}_{2}$ was reported previously ${ }^{41), 42}$. Addition of $\mathrm{TiO}_{2}$ facilitated the reduction from $\mathrm{Mo}^{6+}$ to $\mathrm{Mo}^{4+}$ and enhanced formation of the CoMoS active slab. In addition, the concentration of $\mathrm{Ti}^{3+}$ species which forms the TiMoS phase increased with higher amount of $\mathrm{TiO}_{2}$ from 10 to $20 \mathrm{wt} \%$. TiMoS is formed by coating $\mathrm{TiO}_{2}$ on $\mathrm{Al}_{2} \mathrm{O}_{3}{ }^{15), 16), 40)}$. The previous research also showed that coated $\mathrm{TiO}_{2}$ increased the dispersion of Mo. Consequently, CoMoS and TiMoS were formed effectively ${ }^{15}$. Under a $\mathrm{H}_{2}$ atmosphere, the reduction of $\mathrm{TiS}_{2}$ accelerated to the formation of anion vacancies that be measured by the ESR method and acted as an electronic promoter of the molybdenum sulfide phase ${ }^{37)}$. NO chemisorption (Table 1) showed that the adsorbed amount of NO was increased with higher amount of $\mathrm{TiO}_{2}$ coating. These results suggested that the CoMoS phase and some TiMoS phase were formed effectively with $\mathrm{TiO}_{2}$ coating onto $\mathrm{Al}_{2} \mathrm{O}_{3}$. Therefore, the $\mathrm{HDO}$ yield was increased, and DCO yield decreased with higher $\mathrm{TiO}_{2}$ coating amount. Focusing on the yield of oxygenates compounds, TiMoS had no deoxygenation activity because the yield did not change at $300{ }^{\circ} \mathrm{C}$ and $325^{\circ} \mathrm{C}$ even with increased amount of $\mathrm{TiO}_{2}$ coating. No significant change in isomerization and cracking yield was observed with higher amounts of $\mathrm{TiO}_{2}$ coating. Therefore, TiMoS does not have isomerization and cracking activity. The suggested reaction mechanism over the sulfided $\mathrm{CoMo} / \mathrm{Ti}^{-} \mathrm{Al}$ is presented in Scheme 2.

\section{Conclusions}

Based on the HDO results for $\mathrm{Mo} / \mathrm{Al}_{2} \mathrm{O}_{3}$ and CoMo (0.35) $/ \mathrm{Al}_{2} \mathrm{O}_{3}$, addition of Co increased both deoxygenation activity but promoted the DCO reaction. We suggested that $\mathrm{MoS}_{2}$ has HDO activity, $\mathrm{Co}_{9} \mathrm{~S}_{8}$ has DCO activity, and the CoMoS phase has both HDO and DCO activity. $\mathrm{CoMo}(0.05) / \mathrm{Al}_{2} \mathrm{O}_{3}$ showed the best yield of $n-\mathrm{C}_{16}$ and $n-\mathrm{C}_{18}(87.1 \%)$ among the CoMo catalysts due to the optimum amount of CoMoS phase on the $\mathrm{Al}_{2} \mathrm{O}_{3}$ support. On the other hand, $\mathrm{CoMo}(0.35) / \mathrm{Al}_{2} \mathrm{O}_{3}$ with the highest amount of $\mathrm{Co}$ added showed the lowest HDO yield and the highest DCO yield among the CoMo catalysts. Co addition could improve the HDO activity, but excess addition of Co resulted in decarbonylation and/or DCO because of the presence of excess amount of CoMoS phase. The optimum mole ratio of $\mathrm{Co} / \mathrm{Mo}$ was 0.05 . Based on the activity comparison of $\mathrm{TiO}_{2}$ coating catalysts, $\mathrm{CoMo}(0.05) / \mathrm{Ti}(20)-\mathrm{Al}$ showed the best yield of $n-\mathrm{C}_{16}$ and $n-\mathrm{C}_{18}(88.0 \%)$. Based on the result of $\mathrm{H}_{2}$-TPR and pulse $\mathrm{NO}$ chemisorption, CoMo(0.05)/Ti(20)-Al contains TiMoS phase, which has HDO activity. However, TiMoS did not have deoxygenation activity, isomerization activity, and cracking activity, but favored formation of $n-\mathrm{C}_{16}$ and $n-\mathrm{C}_{18}$.

\section{Supporting information}

Supplementary data associated with this article can be found in the online version at https://jstage.jst.go.jp/ browse/jpi/-char/en (DOI: doi.org/10.1627/jpi.65.18).

\section{References}

1) Sharma, S. D., Sagara, K., Int. J. Green Energy, 2, (1), 1 (2005).

2) Kim, K., Higai, D., Hou, X., Peng, M., Qian, E. W., Ind. Eng. Chem. Res. Am. Chem. Soc., 60, (7), 2881 (2021).

3) Buddhi, D., Sharma, S. D., Energy Convers. Manag., 40, (18), 1979 (1999).

4) Iqbal, K., Khan, A., Sun, D., Ashraf, M., Rehman, A., Safdar, F., Basit, A., Maqsood, H. S., J. Text. Inst., 110, 625 (2019).

5) Gong, S., Chen, N., Nakayama, S., Qian, E. W., J. Mol. Catal. A Chem., 370, 14 (2013).

6) Gong, S., Shinozaki, A., Qian, E. W., Ind. Eng. Chem. Res. Am. Chem. Soc., 1 (2012).

7) Chen, N., Wang, N., Ren, Y., Tominaga, H., Qian, E. W., J. Catal., 345, 124 (2017).

8) Chen, N., Ren, Y., Qian, E. W., J. Catal., 334, 79 (2016).

9) Chen, N., Gong, S., Qian, E. W., Appl. Catal. B: Environ., 174-175, 253 (2015).

10) Qian, E. W., Chen, N., Gong, S., J. Mol. Catal. A Chem., 387, 76 (2014).

11) Gajardo, P., Mathieux, A., Grange, P., Delmon, B., Appl. Catal., 3, 347 (1982).

12) Li, Z. Q., Wang, Y., Yin, C. J., Ren, X. X., Qiu, Z. G., Ranliao Huaxue Xuebao/Journal Fuel Chem. Technol., 49, 522 (2021).

13) Ryymin, E. M., Honkela, M. L., Viljava, T. R., Krause, A. O. I., Appl. Catal. A: General, 389, (1-2), 114 (2010).

14) Nguyen, T. T., Qian, E. W., Microporous Mesoporous Mater., 265, (October 2017), 1 (2018).

15) Nguyen, T. T., Imai, K., Pu, J., Qian, E. W., Energy \& Fuels, 
32, (2), 1665 (2018).

16) Primo, A., Concepción, P., Corma, A., Chem. Commun., 47, (12), 3613 (2011)

17) Liu, R., Yu, Y., Yoshida, K., Li, G., Jiang, H., Zhang, M., Zhao, F., Fujita, S., Arai, M., J. Catal., 269, (1), 191 (2010).

18) Kaluža, L., Karban, J., Gulková, D., React. Kinet. Mech. Catal., 127, (2), 887 (2019).

19) Gapor Md Top, A., Lipid Technol., 22, (1), 11 (2010).

20) Kabe, T., Qian, W., Hirai, Y., Li, L., Ishihara, A., J. Catal., 190, (1), 191 (2000).

21) Brunauer, S., Emmett, P. H., Teller, E., J. Am. Chem. Soc., 60, (2), 309 (1938).

22) Barrett, E. P., Joyner, L. G., Halenda, P. P., J. Am. Chem. Soc., 73, (1), 373 (1951).

23) Nguyen, T. T., Shinozaki, A., Qian, E. W., J. Jpn. Petrol. Inst., 60, (6), 301 (2017).

24) Qian, W., Ishihara, A., Okoshi, Y., Nakakami, W., Godo, M., Kabe, T., J. Chem. Soc.-Faraday Trans., 93, (24), 4395 (1997).

25) Qian, W., Ishihara, A., Aoyama, Y., Kabe, T., Appl. Catal. A: General, 196, (1), 103 (2000).

26) Günter, R. J., Marks, O., Korányi, T. I., Paál, Z., Appl. Catal., 39, (C), 285 (1988).

27) Qian, E. W., Hachiya, Y., Hirabayashi, K., Ishihara, A., Kabe, T., Hayasaka, K., Hatanaka, S., Okazaki, H., Appl. Catal. A: General, 244, (2), 283 (2003).

28) Kaluža, L., Kubička, D., React. Kinet. Mech. Catal., 122, (1),
333 (2017).

29) Arora, P., Ojagh, H., Woo, J., Lind Grennfelt, E., Olsson, L., Creaser, D., Appl. Catal. B: Environ., 227, (January), 240 (2018).

30) Kouachi, K., Lafaye, G., Pronier, S., Bennini, L., Menad, S., J. Mol. Catal. A Chem., 395, 210 (2014).

31) Ishihara, A., Dumeignil, F., Morimoto, K., Qian, E. W., Kabe, T., Inoue, S., Muto, A., J. Jpn. Petrol. Inst., 50, (3), 154 (2007).

32) Qian, E. W., Hachiya, Y., Hirabayashi, K., Ishihara, A., Kabe, T., Hayasaka, K., Hatanaka, S., Okazaki, H., Appl. Catal. A: General, 244, (2), 283 (2003).

33) Kabe, T., Ishihara, A., Qian, W., Yao, P., J. Catal., 210, (2), 319 (2002).

34) Khan, S., Kay Lup, A. N., Qureshi, K. M., Abnisa, F., Wan Daud, W. M. A., Patah, M. F. A., J. Anal. Appl. Pyrolysis, 140, (March), 1 (2019).

35) Mijoin, J., Thévenin, V., Garcia Aguirre, N., Yuze, H., Wang, J., Li, W. Z., Pérot, G., Lemberton, J. L., Appl. Catal. A: General, 180, (1-2), 95 (1999).

36) Ishihara, A., Dumeignil, F., Wang, D., Li, X., Arakawa, H., Qian, E. W., Inoue, S., Muto, A., Kabe, T., Appl. Catal. A: General, 292, (1-2), 50 (2005).

37) Wang, D., Qian, W., Ishihara, A., Kabe, T., J. Catal., 203, (2), 322 (2001).

38) Ishihara, A., Lee, J., Dumeignil, F., Higashi, R., Wang, A., Qian, E. W., Kabe, T., J. Catal., 217, (1), 59 (2003).

\title{
要旨
}

\section{パーム脂肪酸蒸留物の選択的水素化処理硫化 Mo 系触媒における助触媒効果および担体の役割}

\author{
金 基訓, 川野 優生, 檜貝 大輔, Xiaofan Hou, Mingming PENG, 銭 衛華 \\ 東京農工大学生物応用システム科学府, 184-8588 東京都小金井市中町2-24-16
}

異なる $\mathrm{Co} / \mathrm{Mo}$ モル比を持つ $\mathrm{CoMo} / \mathrm{Al}_{2} \mathrm{O}_{3}$ 触媒および $\mathrm{Al}_{2} \mathrm{O}_{3}$ に 異なる量の $\mathrm{TiO}_{2}$ をコーティングした担体を用いて, CoMo/ $\mathrm{TiO}_{2}-\mathrm{Al}_{2} \mathrm{O}_{3}$ 触媒を調製した。これらの触媒を用いたパーム脂肪 酸蒸留物 (PFAD) の水素化処理反応を行い, Co/Mo モル比と $\mathrm{TiO}_{2}$ コーティング量の水素化脱酸素反応（HDO）および脱炭 酸／脱カルボニル化反応（DCO）に及ぼす影響を検討した。 触媒解析には, BET, XRF, NOパルス吸着法と $\mathrm{H}_{2}-\mathrm{TPR}$ を用 いた。Co/Mo モル比が 0.05 では $n-\mathrm{C}_{16}$ および $n-\mathrm{C}_{18}$ の収率が最
大になったが, それより高い $\mathrm{Co} / \mathrm{Mo}$ モル比では $n-\mathrm{C}_{15}$ および $n-\mathrm{C}_{17}$ の収率が上昇した。この結果から触媒上の $\mathrm{CoMoS}$ 層が HDO と DCO の両方の活性を持つことが分かった。全ての触媒 の中で, $\mathrm{CoMo}(0.05) / \mathrm{Ti}(20)-\mathrm{Al}$ が最も高い $n-\mathrm{C}_{16}$ と $n$ - $\mathrm{C}_{18}$ の収率 を示した。これらの結果から, $\mathrm{Al}_{2} \mathrm{O}_{3}$ 上に $\mathrm{TiO}_{2}$ を添加すること で形成された TiMoS 相は, HDO 反応を促進するが, 異性化お よびクラッキング活性を持たないことが示唆された。 